\title{
DÜBLIN
}

Technological University Dublin ARROW@TU Dublin

\section{A review of human factors and food safety in Ireland}

\author{
Ciara Walsh \\ Technological University Dublin, ciara.walsh@tudublin.ie \\ Maria Chiara Leva \\ Technological University Dublin, maria.leva@tudublin.ie
}

Follow this and additional works at: https://arrow.tudublin.ie/schfsehart

Part of the Environmental Health Commons, and the Food Science Commons

\section{Recommended Citation \\ Ciara Walsh, Maria Chiara Leva, A review of human factors and food safety in Ireland, Safety Science, Volume 119, 2019, Pages 399-411, ISSN 0925-7535, DOI: 10.1016/j.ssci.2018.07.022.}

This Article is brought to you for free and open access by the School of Food Science and Environmental Health at ARROW@TU Dublin. It has been accepted for inclusion in Articles by an authorized administrator of ARROW@TU Dublin. For more information, please contact arrow.admin@tudublin.ie, aisling.coyne@tudublin.ie, gerard.connolly@tudublin.ie.

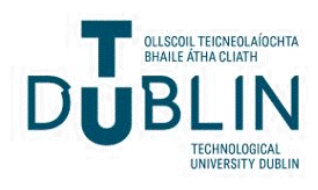




\title{
A review of human factors and food safety in Ireland
}

\author{
Ciara Walsh*, Maria Chiara Leva \\ School of Food Science \& Environmental Health, College of Sciences and Health, Dublin Institute of Technology, Cathal Brugha Street, Dublin 1, Ireland
}

\section{A R T I C L E I N F O}

\section{Keywords:}

Human factors

Risk assessment

Food safety

Good hygiene practice

Training

HACCP

\begin{abstract}
A B S T R A C T
Increased product shelf-life and globalisation have led to longer and vastly more complicated food chains; potentially presenting greater opportunity for contamination and microbial growth to occur. Modern food safety management systems risk assess hazards (based on current scientific data) and strive to control these, often extensive and convoluted, food production/supply chains through appropriate good hygiene practices (GHP) and HACCP. Contamination of food as a result of human error can undermine even the most carefully prepared and executed HACCP system - culminating in foodborne infection, outbreaks, reputable damage, and erosion of consumer trust. This paper provides a review on the effect of human factors on the food sector in Ireland. Figures on foodborne outbreaks, laboratory analysis of ready-to-eat (RTE) foods, and crude incidence rate (CIR) per 100,000 population of infection were examined; in order to gain insight into the occurrence of food safety breaches in Ireland. Food safety legislative requirements and recommendations for Irish food businesses are considered, along with rates of inspection and enforcement. An average of 86 closure orders are issued in Ireland every year as a result of breaches, which can be generally either partially/fully attributed to human factors. This paper examines the critical role of human factors in safe food production; and includes data from Irish surveys on food safety training (food handlers and trainers) and food safety violations in a selection of Irish food premises.

Food business owners need to commit time and resources to identifying, risk assessing, and addressing the potential role of 'human error' in their facility - whether intentional, unintentional, direct, or indirect. Appropriate recognition of the importance of human factors in food safety management, coupled with a high standard of training and appropriate implementation of food safety principles is necessary to safeguard modern food businesses.
\end{abstract}

\section{Food safety: the relevance of the problem globally and in Ireland}

Foodborne illnesses are usually infectious, or toxic, in nature and caused by bacteria, viruses, parasites or chemical substances entering the body through contaminated food, or water. Foodborne pathogens (disease causing organisms) can cause vomiting, severe diarrhoea, other debilitating illnesses, or in some cases even death. The burden of foodborne disease on public health/welfare, and even the economy, is often underestimated due to underreporting and difficulties in establishing a direct relationship between contaminated food and the resulting illness, or death (Nsoesie et al., 2014; WHO, 2017). Unsafe food poses a global health threat to all, especially infants, young children, pregnant women, the elderly, and immunocompromised individuals. The WHO (2017) report that 220 million children contract diarrhoeal disease annually, with an associated 96,000 mortalities. In fact, an estimated 600 million (almost 1 in 10 people in the world) fall ill after eating contaminated food, and approximately 420,000 individuals die annually. Furthermore, it is estimated that in the developing world more than one-third of the total population are affected by foodborne disease each year (Baser et al., 2017). Suffice to say, this burden is comparable to other major infectious diseases such as HIV/Aids, malaria and tuberculosis (Havelaar et al., 2015).

From a developed world perspective, the European Food Safety Authority (EFSA, 2015) reported a total of 5196 foodborne outbreaks and waterborne outbreaks in the EU in 2013 (43,183 human cases, 5946 hospitalisations and 11 deaths), however a substantial amount of underreporting is suspected (Nsoesie et al., 2014; Kruse, 2015). Interestingly, the figure for foodborne illness derived from food services in food production premises is reported to be anywhere between $43 \%$ up to $60 \%$ (WHO, 2003; Jones and Angulo, 2006; EFSA, 2010; CDC, 2013). In Ireland it has been suggested that approximately $50 \%$ of foodborne outbreaks can be traced back to food eaten in catering establishments (Bolton et al., 2008), and the overall cost of gastronenteritis (regardless of source) is conservatively estimated to be approximately 135 million euro per annum (Safefood, 2007).

\footnotetext{
* Corresponding author.

E-mail address: Ciara.walsh@dit.ie (C. Walsh).
} 


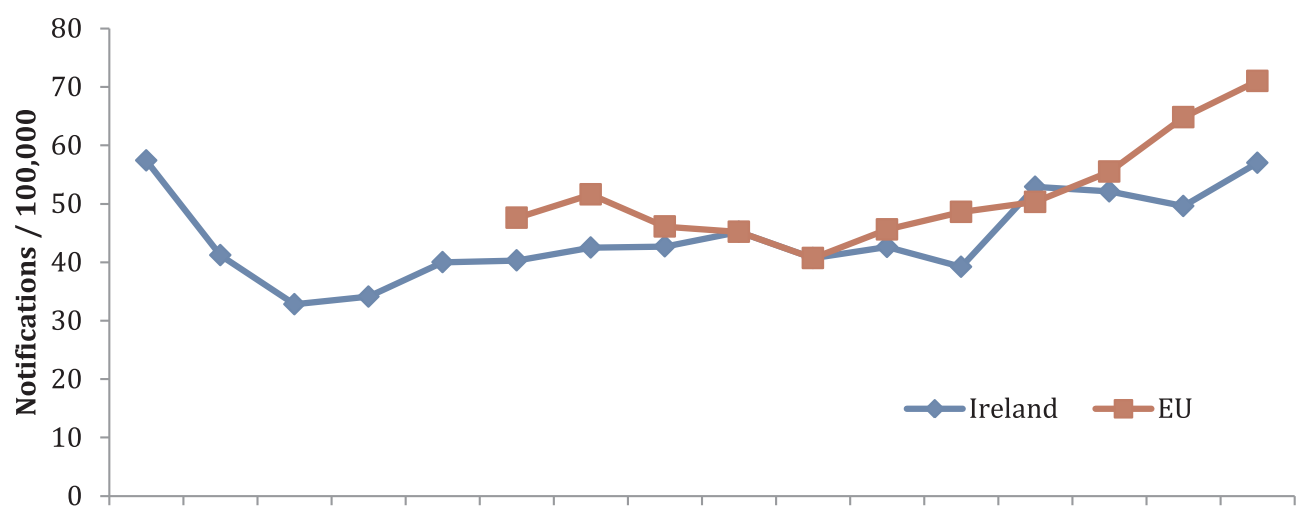

1999200020012002200320042005200620072008200920102011201220132014

Year

Fig. 1. Crude Incidence Rate of Campylobacteriosis notifications per 100,000 population in Ireland from 1999 to 2014 and EU from 2004 to 2014. Source: FSAI Zoonosis Update, HPSC \& EFSA.

An examination of the most recent available data for Ireland, shows Campylobacter spp. to be the most common cause of bacterial gastroenteritis - a similar trend is being observed in the rest of the EU (Fig. 1) (FSAI, 2017). There were 2616 cases of human campylobacteriosis reported in Ireland in 2014, corresponding to a crude incidence rate (CIR) of 57 cases per 100,000 population; compared to an EU average CIR of 71 cases per 100,000 population (FSAI, 2017). Fig. 1. shows a varying, but relatively similar CIR for Ireland and the EU between 2004 and 2012; with Ireland having a slightly lower CIR than the EU average in 2013 and 2014. While it is generally accepted that a large degree of foodborne illness goes unreported (Nsoesie et al., 2014), figures provided by the Health Protection Surveillance Centre (HPSC) were used to calculate an average occurrence of foodborne outbreaks in Ireland for various pathogens (Table 1). Based on these data, an average of one outbreak of campylobacteriosis per year (where foodborne transmission is suspected) occurs in Ireland, with approximately 5 associated individuals becoming ill (Table 1). In addition, the average percentage of ready-to-eat (RTE) foodstuffs contaminated with Campylobacter spp. (a reported 4917 samples analysed between 2008 and 2013) in the samples tested in Ireland (FSAI, 2017), was calculated as 0.1\% (Table 2). The results of the RTE foods tested in Ireland for Campylobacter spp. (and other foodborne pathogens in this study) were reported, as oppose to the raw samples, as these foodstuffs are unlikely to receive any further processing prior to human consumption.

In 2014, there were 260 cases of salmonellosis reported in Ireland, a CIR of 5.7 per 100,000 population; which was less the European average CIR of 23.4 per 100,000 population (FSAI, 2017). In fact, the Irish CIR has been below the European average CIR since 2004 (Fig. 2). The majority of the isolates $(n=258)$ recovered in 2014 were referred to the National Salmonella, Shigella and Listeria Reference Laboratory (NSSLRL) in Ireland for typing. Similar to previous years (FSAI 2017), Salmonella Typhimurium (including monophasic S. Typhimurium) ( $\mathrm{n}=107,41.5 \%)$ and Salmonella Enteritidis $(\mathrm{n}=44,17.1 \%)$ were identified as the predominant isolates associated with human salmonellosis in Ireland. Based on data provided by the HPSC (2008-2015) (Table 1), an average of five outbreaks were estimated to occur in Ireland every year where foodborne transmission was suspected, with approximately 29 associated individuals becoming ill. The average percentage of ready-to-eat (RTE) foodstuffs contaminated with Salmonella spp. (a total of 107,364 samples analysed between 2008 and 2013), in the samples tested in Ireland (FSAI, 2017), was calculated as approximately $0.06 \%$ - nearly half of that indicated for Campylobacter spp. $(0.1 \%)$ (Table 2$)$.

With regard to Verotoxigenic E. coli (VTEC), there were 707 notifications in 2014, with a CIR of 15.4 per 100,000 population (FSAI, 2017). This is almost 10 times the EU average CIR of 1.56 per 100,000 population (Fig. 3). In fact, Ireland has reported the highest VTEC incidence rate of any Member State in the EU in recent years; with the exception of the German VTEC O104 outbreak linked to fenugreek seeds in 2011 (FSAI, 2017). These high levels are a concern, given the low infectious dose (potentially 10 cells) and high virulence associated with VTEC: often resulting in severe and life threatening illness, particularly in young children, the elderly and immuno-compromised individuals (Walsh et al., 2006). Based on the HPSC data (2008-2015) (Table 1), an average of three VTEC related outbreaks have been estimated to occur in Ireland every year (where foodborne transmission is suspected), with approximately 11 associated individuals becoming ill. The environmental persistence of VTEC in Ireland can be attributed to a large ruminant population and a favourable, mild, wet climate (Chekabab et al., 2013). Cattle are considered to be an important reservoir host of Escherichia coli O157:H7 (and other VTEC serotypes) and contaminated foods of bovine origin can be a vehicle for human infection (Walsh et al., 2006). The average percentage of RTE foodstuffs containing VTEC (a total of 2187 samples analysed between 2008 and 2013), in the samples tested in Ireland (FSAI, 2017), was calculated as $0.05 \%$ (Table 2). Previous Irish studies have reported that the prevalence of $E$. coli 0157 in raw minced meat and beef burgers at approximately $2.8 \%$ (Cagney et al., 2004), and $0.25 \%$ for E. coli $\mathrm{O} 111$ and O26 (FSAI, 2004). The high prevalence of VTEC in Ireland reinforces the importance of appropriate hygiene practices (in order to prevent cross-contamination), and adequate cooking regimes (particularly with regard to minced meat and related products), in order to prevent possible foodborne transmission.

Fifteen cases of listeriosis were notified in Ireland in 2014 and the CIR was reported as 0.3 per 100,000 population (FSAI, 2017). Listeriosis in Ireland was below the 2014 European average CIR $(0.52$ per 100,000 population) and has been since 2004 (Fig. 4). Between 2008 and 2016, there were 106 notifications of listeriosis in Ireland, however no foodborne outbreaks were reported (HPSC, 2017). During an investigation of some of these sporadic cases, foods typically associated with listeriosis were tested, however none were implicated microbiologically. Although listeriosis is generally believed to occur through the consumption of contaminated food, it is often very difficult to identify its source. One important reason being the relatively long incubation period associated with listeriosis, which ranges between 3 and 70 days (average incubation period is 3 weeks). For this reason, investigations are often limited to a patient's ability to recall pertinent food items over such a long period of time.

The average percentage of RTE foodstuffs containing Listeria spp. (a total of 11,068 samples analysed using the 'detection' method between 2008 and 2013), in the samples tested in Ireland (FSAI, 2017), was calculated as $1.4 \%$ (Table 2). In addition, the average percentage of 


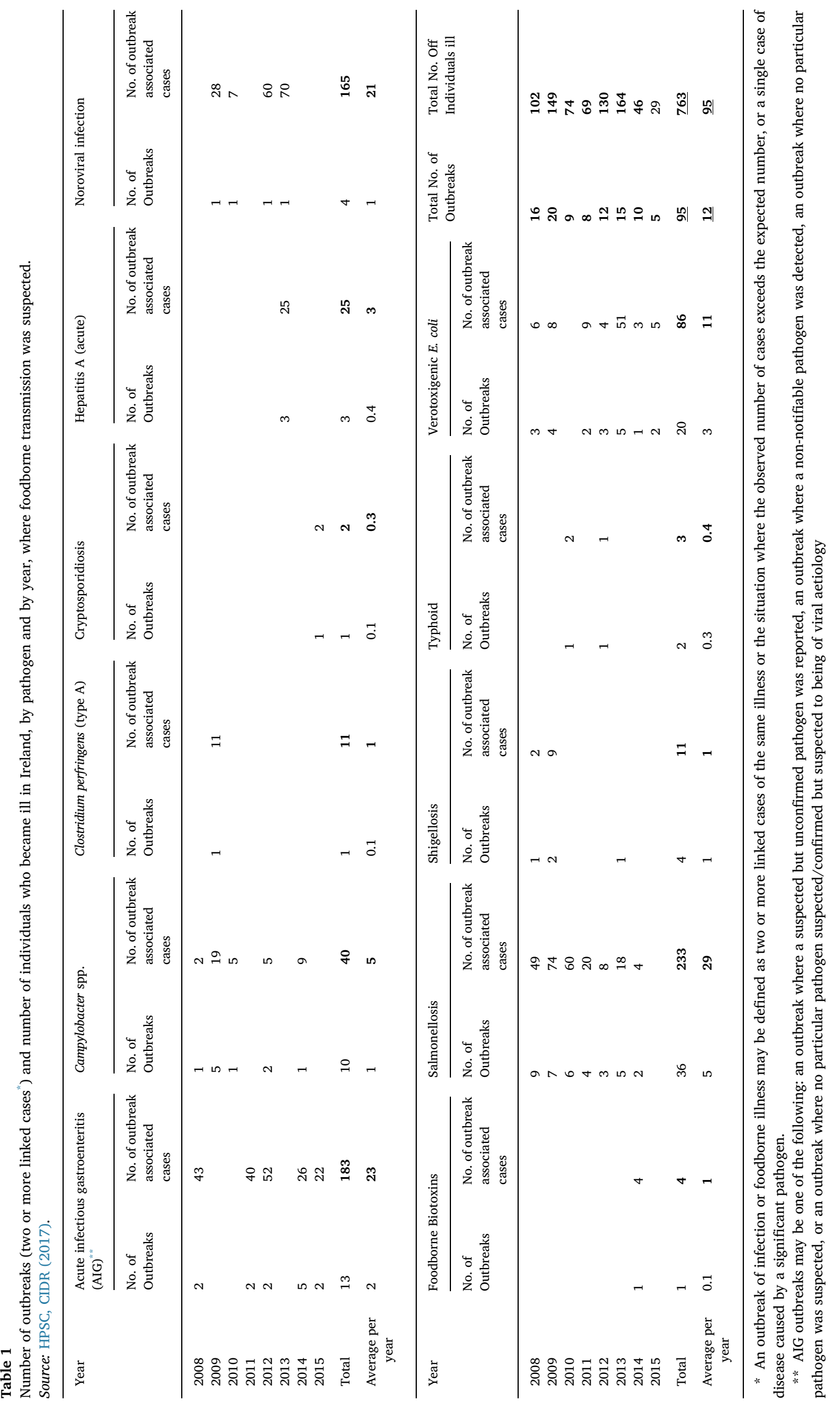




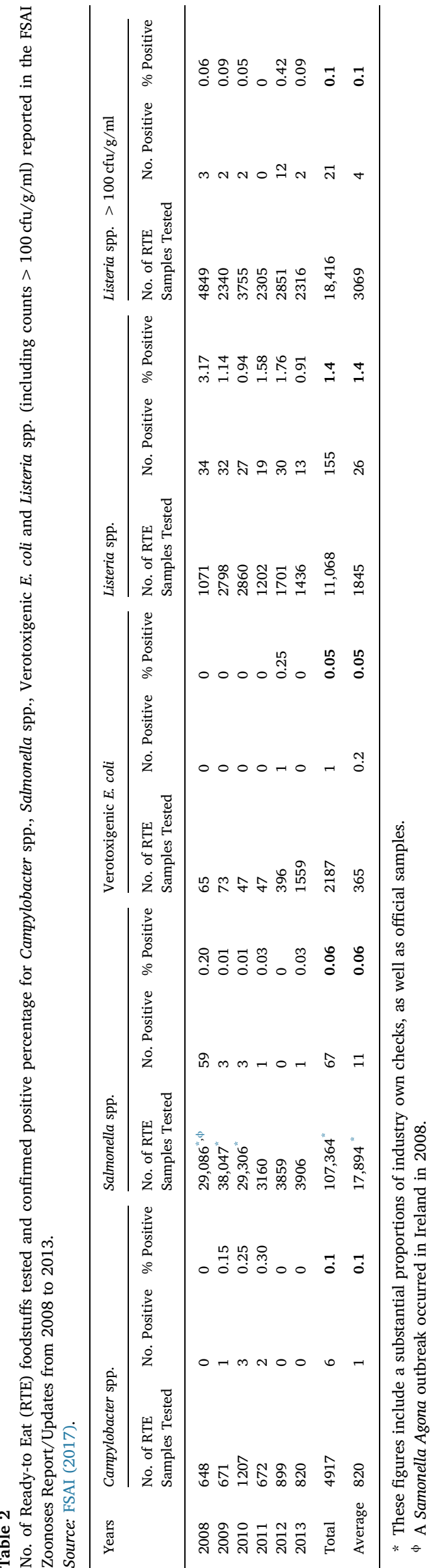

RTE foodstuffs containing $>100 \mathrm{cfu} / \mathrm{g} / \mathrm{ml}$ of Listeria spp. (a total of 18,416 samples analysed using the 'enumeration' method between 2008 and 2013) was $0.1 \%$ (Table 2). From a food processing perspective, control of Listeria spp. can be problematic. This is most likely due to the fact that it is ubiquitous in nature, typically resistant to salt and acidity conditions and able to survive/ grow at (or below) normal refrigeration temperatures. Control of $L$. monocytogenes is required at all stages of the food chain and an integrated approach, including the effective implementation of good hygiene practices (GHP), HACCP, and testing against microbiological criteria Regulation (EC) 2073/2005 (where applicable), is required (FSAI, 2017). While listeriosis is typically characterised by gastroenteritis and fever in healthy individuals, infection in vulnerable groups such as neonates, the elderly, immunocompromised, or pregnant women, can be associated with more serious complications - such as premature delivery, intrauterine death, septicaemia, or meningitis. From this perspective pregnant women in Ireland, like their European counterparts, are advised to avoid food products such as soft cheese, paté etc., in order to further reduce their possible risk of infection (Safefood, 2008). Norovirus is a common cause of acute gastroenteritis in the community, and was associated with 4 foodborne outbreaks in Ireland involving 165 individuals in recent years (Table 1). Its mode of transmission is generally direct, person to person, so its association with food would be described as indirect: through contamination of food by handling or from the surrounding environment. Previous sources have included foods such as cold meats, salads or sandwiches; which became contaminated during handling and did not receive further processing/heat treatment. In addition, bivalve molluscan shellfish such as oysters can harbour the virus through filter feeding of contaminated water (FSAI, 2013), and can then be eaten uncooked. From a food safety perspective, FBOs must ensure that food workers do not work when unwell (or for more than 48 hours after symptoms cease for Norovirus), and be prepared to respond quickly and correctly should a food handler vomit in a food area e.g. discard surrounding food, decontaminate using a $1 \%$ bleach solution etc. (NHP, 2016)

\section{Requirements for risk assessment and safety management of foodstuffs in Ireland}

General Food Law (Regulation (EC) 178/2002) sets out the general principles and requirements of food law, in particular the definition of 'unsafe' food. EU Rules regarding Food Hygiene regulates all stages of production, processing, distribution and placing on the market of food intended for human consumption. Rules on the hygiene of foodstuffs were adopted in April 2004 by the European Parliament and the Council (Regulation (EC) No 852/2004, 853/2004, 854/2004 and 882/ 2004) and became applicable on the 1st of January 2006, as per Fig. 5. The 2004 rules merged, harmonised, and simplified, complex Council Directives previously covering the hygiene of foodstuffs and products of animal origin (EC, 2009).

Regulation (EC) $852 / 2004$ on the hygiene of foodstuffs must be correctly implemented by all food businesses in order to ensure food safety. It requires that food businesses register with a competent authority before commencing operations, with a view to future visits and inspections. In addition, food businesses that handle food of animal origin must also implement the appropriate requirements of Regulation (EC) No 853/2004, and depending on their activities in Ireland may need to seek formal approval e.g. the Department of Agriculture, Food and the Marine (DAFM), Sea-Fisheries Protection Authority (SFPA) etc., in addition to registration.

Article 5 of Regulation (EC) 852/2004 requires that food business operators shall put in place, implement and maintain a permanent procedure/s based on the principles of Hazard Analysis at Critical Control Points (HACCP). The prerequisite hygiene requirements, or GHP, provide the foundation for the effective implementation of HACCP and should therefore be in place before HACCP based 


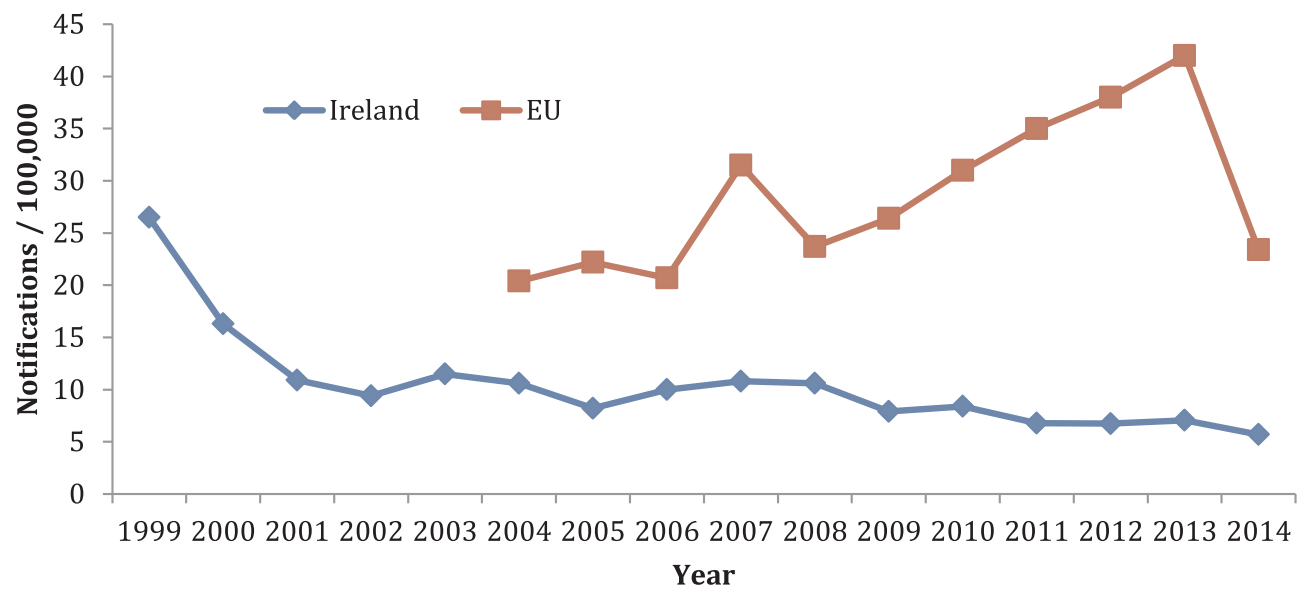

Fig. 2. Crude Incidence Rate of Salmonellosis Notifications per 100,000 population in Ireland from 1999 to 2014 and in the EU from 2004 to 2014. Source: FSAI Zoonosis Update, HPSC \& EFSA.

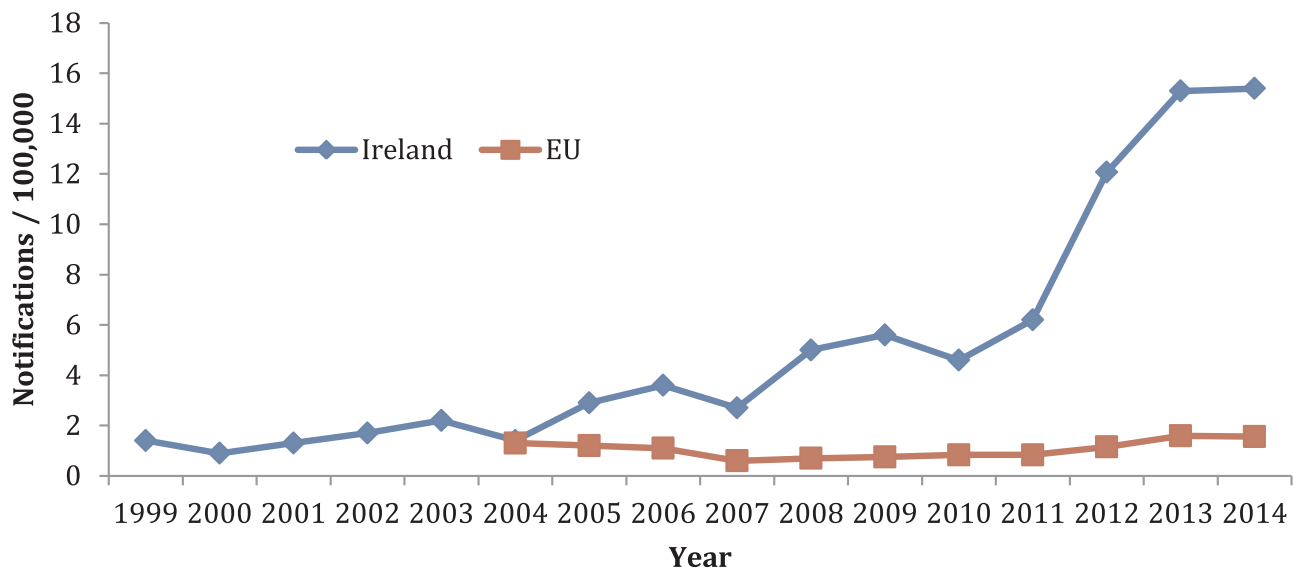

Fig. 3. Crude Incidence Rate of VTEC Notifications per 100,000 population in Ireland from 1999 to 2014 and in the EU from 2004 to 2014. Source: FSAI Zoonosis Update, HPSC \& EFSA.

procedures are established; often referred to as the prerequisite programme (PRP) (Motarjemi, 2014). The PRP includes general requirements dealing with structural, operational and personal hygiene, (Annex II of this Regulation) as per Table 3, and specific requirements including maintenance of the cold chain (Article 4 of this Regulation).
The obligation to maintain the cold chain is a prerequisite hygiene requirement, and must be implemented even when simplified HACCP based procedures are applied (FSAI, 2007).

It is noteworthy that in order to ensure that solutions for specific situations are available without compromising food safety, Regulation

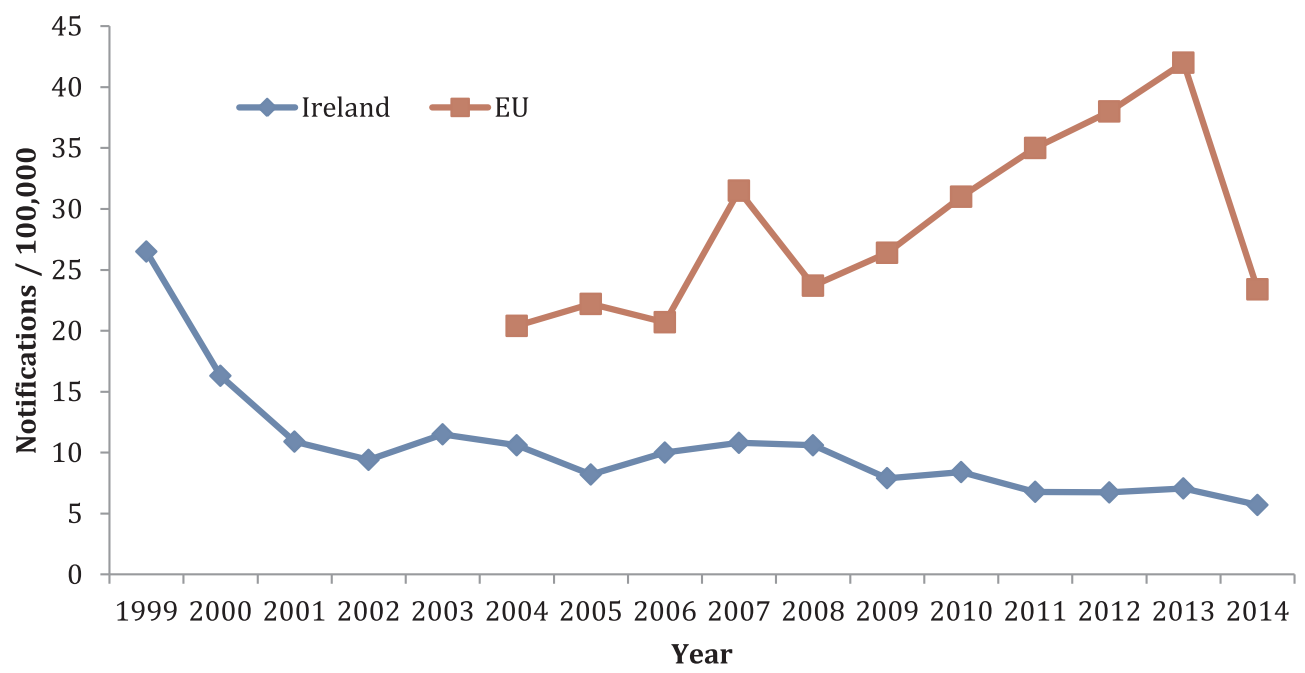

Fig. 4. Crude Incidence Rate of Listeriosis Notifications per 100,000 population in Ireland from 1999 to 2014 and in the EU from 2004 to 2014. Source: FSAI Zoonosis Update, HPSC \& EFSA. 


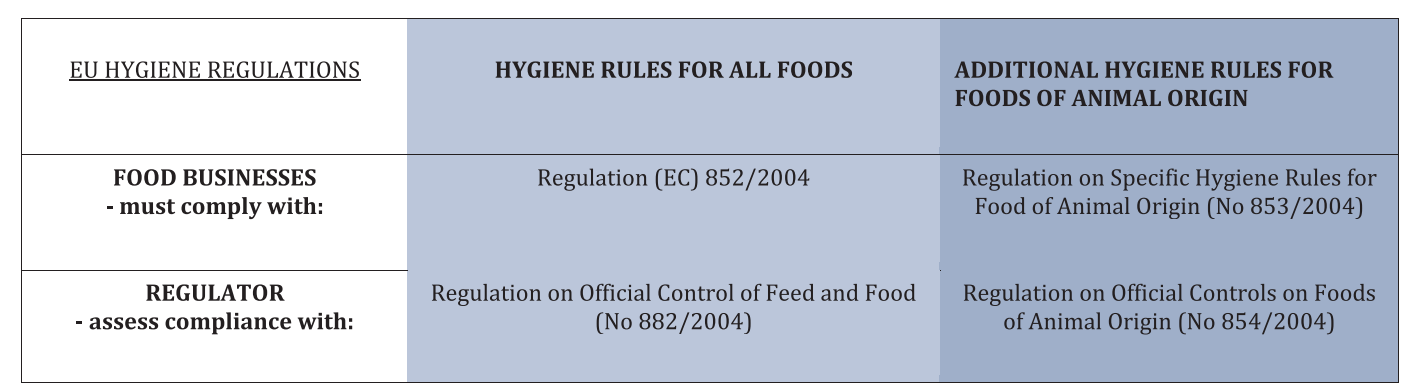

Fig. 5. EU Hygiene Rules for All Foods and Foods of Animal Origin. "Other food safety legislation of note includes: Regulation (EC) 178/2002 (sets out the general principles and requirements of food law), Regulation (EC) No 2073/2005 (microbiological criteria for foodstuffs) and Regulation (EC) No 2074/2005 (implementing measures for certain products and organisation of official controls).

Table 3

General hygiene requirements (as per Article 4(2) and Annex II of Regulation (EC) No. 852/2004) require food business operators to comply with the following.

Source: FSAI (2007).

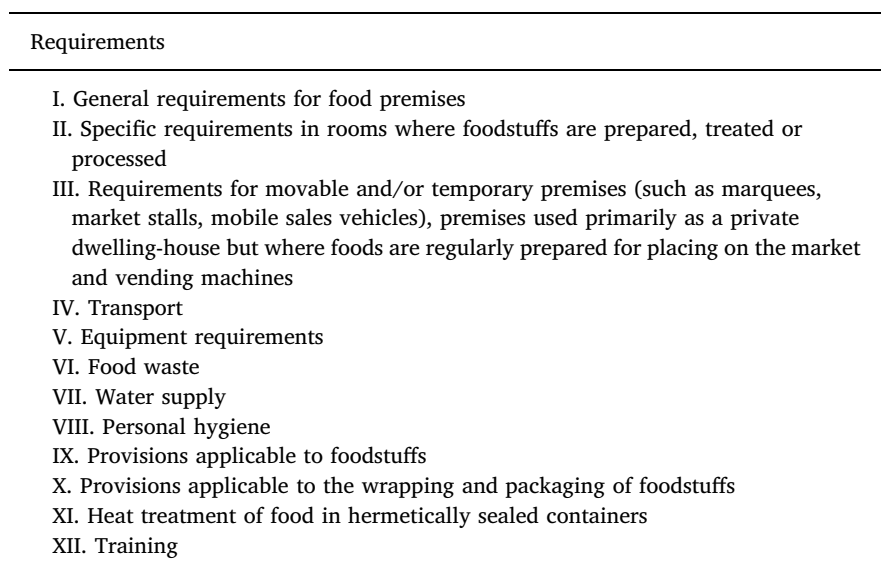

(EC) $852 / 2004$ provides 'flexibility' in its application (EC, 2009). For instance, where the prerequisite hygiene requirements achieve the objective of controlling hazards in a food business, it is considered that 'based on the principle of proportionality' that the requirements of Article 5 have been met (FSAI, 2007). From this perspective, the FSAI recommends that Irish food business adhere to one of three compliance options, depending on their activities: controlling hazards by means of the PRP only, a recognized guide, or a HACCP based system based on the HACCP principles (FSAI, 2007).

\section{Food safety training in Ireland}

Training is also an important tool to ensure the effective application of good hygienic practices (Annex II, Regulation (EC) 852/2004). A food business operator (FBO) should ensure that all staff working with food have sufficient knowledge to carry out their activities in a safe and hygienic manner. In this regard, and as per EU food law, the FBO must ensure that all staff are supervised, instructed and/or trained in hygiene commensurate (or appropriate) to their work activities. Flexibility also exists with regard to food safety training for food handlers e.g. in-house training, external professional training, e-learning courses etc. In addition, staff responsible for the development, implementation and maintenance of HACCP based procedures should receive adequate training in the HACCP principles and their application. Moreover, the National Hygiene Partnership (NHP) of Ireland recommends that FBOs, chefs, supervisors and food safety decision makers, are trained to a management level (level 3) in food safety (NHP, 2016).

\section{Food safety inspection and enforcement in Ireland}

The FSAI Act 1998, which established the FSAI, also gave authorised officers the power to inspect food businesses for compliance with food safety legislation. Under this Act authorised officers may, if conditions present risks to public health, serve enforcement notices/orders on the FBO. These include: an Improvement Notice (requiring remedial work to be carried out), an Improvement Order (issued by the district court as a result of non-compliance with an Improvement Notice), a Closure Order (closing down a business) or a Prohibition Order (placing restrictions, or prohibitions on the use of foodstuffs).

The Health Service Executive (HSE) is one of several agencies under 'service contract' to the FSAI, and thus undertakes official controls on behalf of the Authority. The HSE inspected an average of 45,471 premises (including primary producers, manufacturers, packers, distributors, food businesses, retailers etc.) a year between 2010 and 2014 (FSAI, 2015a), compared to an average of 2601 by the Sea-Fisheries Protection Authority, 746 by the Department of Agriculture and 457 by local authorities in Ireland during the same time period, respectively. The authors examined the available FSAI figures for enforcement orders served in Ireland between 2010 and 2014 (FSAI, 2016a) (Table 4). From these data, the average percentage of closure orders served on premises was calculated at less than $0.2 \%$ of those inspected, less than $0.04 \%$ for prohibition orders, and less than $0.01 \%$ for improvement orders, respectively

In more general terms, the FSAI carried out analysis (in 2013) of the specific breaches reported by authorised officers which resulted in 'closure orders' being served on food premises (FSAI, 2016a). Table 4 shows that an average of 86 closure orders are issued in Ireland every year and the following were listed (in descending order) as the most 'frequent reason/s' for this enforcement: 'cleaning and sanitation, services, food storage, maintenance, HACCP, pest control programme, training and supervision, prevention of contamination, personal hygiene and monitoring.' While the figures associated with these data were not available, it is noteworthy that the rationale for this enforcement can be typically (either partially/fully) attributed to human

Table 4

The total number of enforcement orders issued between 2010 and 2014 in Ireland.

Source: FSAI (2016a).

\begin{tabular}{llll}
\hline Year & Closure order & Improvement order & Prohibition order \\
\hline 2014 & 96 & 1 & 16 \\
2013 & 119 & 5 & 20 \\
2012 & 91 & 3 & 15 \\
2011 & 66 & 7 & 11 \\
2010 & 57 & 4 & 12 \\
Average per year & $\mathbf{8 6}$ & 4 & $\mathbf{1 5}$ \\
\hline
\end{tabular}


factors. In fact, in a recent press release, the CEO of FSAI reported that food inspectors are encountering the same 'careless food safety practices' 'time and time again' and that the 'reasons why enforcement orders are being served 'are easily avoidable' (FSAI, 2016b) From this perspective, more needs to done to address the important role of that human factors play in safe food production.

\section{The critical role of human error in food safety}

Baser et al. (2017) reports 'application errors' as having an important role in the incidence of foodborne illness, while Nayak and Waterson (2016) suggests that a 'relaxed attitude to food safety' contributes to foodborne outbreaks.

A examination of the literature reveals many risk factors associated with foodborne illness/outbreaks can be attributed to human error, or neglect. In particular, cross-contamination (Collins, 1997; Bolton, 2004; Jones and Angulo, 2006; Choung, 2010) is frequently reported as a major contributor, including the use of contaminated equipment and ineffectively cleaned surfaces - that even remained wet between cleaning steps resulting in the contamination of RTE food (Gill et al., 2001; Evans et al., 2004; FDA, 2009). As mentioned previously (FSAI, 2016a), inadequate cleaning and sanitation has been indicated as the most frequent reason/s for a 'closure order' being served on food premises in Ireland. A study by Howells et al. (2008) examined the perceived barriers to implementing three food safety practices: hand washing, using thermometers, and cleaning work surfaces, in 125 restaurant employees in the US. Time constraints, inconvenience, inadequate training and resources were identified as important reasons for non-compliance. Moreover, lack of incentive and managers not monitoring whether employees cleaned work surfaces, were also listed as contributing factors.

Time and temperature abuse (Collins, 1997; Bolton, 2004; Choung 2010), including holding time and temperatures (FDA, 2009), inadequate cooking (Jones and Angulo, 2006; FDA, 2009; Sanlier, 2009; Nayak and Waterson, 2016) and inadequate cooling (Sanlier, 2009), are also reasons frequently associated with foodborne illness in the literature. Correct time and temperature regimes are essential for the production of safe food, and are typically identified as critical control points (CCP) in food operations. Failure of any of these CCP can be problematic, particularly if food ingredients are contaminated with pathogenic bacteria prior to processing; allowing bacteria to survive/ grow/cross-contaminate etc. An example includes the Irish Salmonella Agona outbreak of 2008, which extended to England, Scotland, Wales and Northern Ireland. The cause was reported to be a batch of undercooked bacon (cooker failure) containing the pathogenic bacteria $S$. Agona; which while removed from production and quarantined, had contaminated the process line (HPSC, 2011). The result of this outbreak was 163 confirmed cases of $S$. Agona and two associated fatalities.

Poor Personal Hygiene (Collins, 1997; Bolton, 2004; FDA, 2009; Choung 2010) and infected staff working with foodstuffs (HPSC, 2004; Sanlier, 2009) are practices often linked to foodborne infection. It is generally accepted that inadequate personal hygiene practices can negatively impact on food safety within a food premises. For example, a study by Fischler et al. (2007) reports that washing with antimicrobial soap can achieve greater than a $3 \log$ reduction in $E$. coli, and between a 2.8 and to a $3.3 \log$ reduction in Shigella flexneri, highlighting the importance of appropriate hand washing practices. In addition, the most common mode of pathogen transmission to food by an infected food handler is via faecally contaminated hands; of which pathogens such as Norovirus, Salmonella spp., Hepatitis A virus (HAV) and E. coli spp., have been previously transmitted (HPSC, 2004; Jones and Angulo, 2006). It is estimated that between 4 and 33\% of outbreaks in the UK are caused by infected employees (Bonner et al., 2001; Guzewich and Ross 1999). Moreover, a study by Hedberg et al. (2006) suggests that the figure for foodborne outbreaks associated with food handled by infected employees in US restaurants, could be as high as $65 \%$. The overriding principle of food handlers not working when they are suffering from diarrhoea and/or vomiting, etc., due to common causes of infectious illness is firmly established (HPSC, 2004). However, even healthy food handlers can be a source of infection, so appropriate hygiene measures e.g. hand washing, sanitising, etc., are required to be in place, and applied in all food businesses.

From this perspective, the implementation of an effective hand washing regime is paramount to safe food production. Soap acts as an emulsifier, which loosens and binds to dirt and micro-organisms allowing them to be washed away.

Biocides such as e.g. sterilisers, disinfectants, sanitisers are also commonly used in the food industry (Walsh and Fanning, 2008; Ryther, 2014.). In particular triclosan, chlorhexidine and para-chloro-metaxylenol (PCMX), have been used for their antibacterial and deodorising attributes in handcare products. While these biocides are known to have antibacterial properties, the benefit of using antimicrobial soap over plain soap is still unproven (Safefood, 2017). In addition, the possibility of increased resistance to other antimicrobials (such as antibiotics) due to their extensive use in consumer products is still being considered (Walsh and Fanning, 2008). While the use of water and soap (conventional and antimicrobial) are historically accepted as an effective method of removing micro-organisms from hands, a residual level of bacteria typically remain (Safefood, 2017). For this reason, a twostep process of thorough hand washing and subsequent sanitiser application are reported to be more effective at reducing microbial contamination, than hand washing alone. In fact, alcohol-based hand sanitising products are reported to achieve a fast and effective level of bacterial inactivation e.g. approximately $4-5 \log _{10}$ reduction of certain bacteria e.g. E. coli, if present (Paulson et al., 1999; Edmonds et al., 2012). In particular, $70 \%$ of alcohol is regarded as the optimum concentration of ethanol to kill micro-organism present; by cell wall penetration and protein/enzyme denaturation. Higher concentrations of alcohol e.g. $>85 \%$, can cause instant cell wall protein coagulation thereby preventing alcohol effectively entering the cell. While alcoholbased hand sanitisers are generally reported to be more effective against bacteria (Rotter 1999) and fungi (Fendler and Groziak 2002) than against viruses, a level of inactivation has been reported to the HIV virus, herpes, rhinovirus, hepatitis, influenza and parainfluenza (Fendler and Groziak 2002). However it is noteworthy that hand sanitisers do not result in complete sterilisation of treated hands (even from bacteria), and that their effectiveness is substantially reduced if a prior hand washing step is omitted. In fact, the level of bacterial inactivation has been reported as limited, approximately $\leq 1-2 \log _{10}$, when tested on hands soiled with food debris (Safefood, 2017). In this regard, the benefit of sterilisers can be lost if 'short cuts' are taken i.e. the hand washing step is skipped by a food handler prior to sanitiser application.

Interestingly variations in water temperature have not been reported to change the bactericidal effect on bacteria present (Todd, 2014; Safefood, 2017), but since comfortable water temperature may encourage a more prolonged hand washing step, warm as oppose to hot/cold water, is advised. In addition, friction, duration, and frequency of hand washing have been reported to be effective parameters in reducing the bacterial load on soiled hands; with the US Food Code recommending a minimum of $20 \mathrm{~s}$ duration (10-15 s vigorous scrubbing). However, studies on food workers and members of the public, suggest that the majority of individuals spend less than $20 \mathrm{~s}$ hand washing (Todd, 2014; Safefood, 2017). Given the importance of effective hand washing practices at appropriate intervals in food premises, managers and chefs should ensure that employees not only understand the reasons for hand washing, but adhere to these practices and receive guidance/training, as applicable. This should be complemented with the necessary signage (to prompt and remind food handlers), and the provision of well-stocked washing stations; preferably with single-use paper towels. Effective drying practices should also be encouraged to prevent microbial spread via residual water, and by removing 


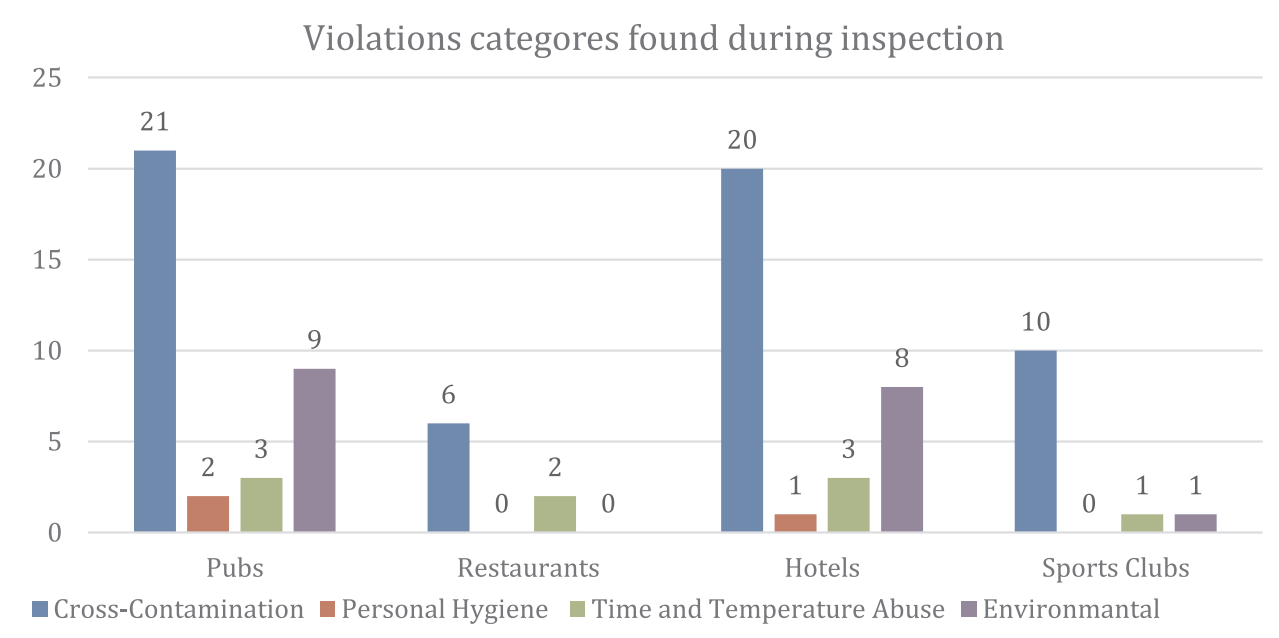

Fig. 6. Violations categories found during inspection of 12 premises ( 3 pubs, 3 restaurants, 3 hotels and 3 sports clubs).

additional micro-organisms on hand surfaces by rubbing (friction).

Consideration should also be given to gloves as a potential vehicle of microbial transmission. While gloves create a physical barrier between human skin and food, they also create a warm, moist, and protective environment for bacterial growth. In addition, there is often a skewed perception among food handlers that protective clothing (PC), such as gloves, are present in order to keep the food handler clean i.e. protect the food handler from the food as oppose to the reverse. Moreover hand washing compliance is reported to be less when gloves are worn (Todd, 2014), so for this reason their use should be monitored by management and enforcement officers alike. The NHP in Ireland (NHP, 2016) recommend that gloves are only used for short periods of time, and for a single operation; and should not be a substitute for hand washing. Hands should also be washed before glove use (and an alcohol- based sterilising solution applied) and after - where necessary. Other important considerations include not touching skin (e.g. face) or clothing with contaminated gloves, changing gloves when heavily soiled or torn, and never washing or reusing them. Other PC should be designed and worn so as not to present a risk to food, washed frequently (changed when soiled) and separately to non-work clothing at high temperatures, not worn outside, and stored away from other clothing. Compliance with appropriate hygiene measures, such as effective hand-washing practices, still remain an important strategy in the prevention of foodborne infection in food premises.

6. Human error and food safety, with particular regard to Ireland: areas for consideration

During 2017, a survey of 100 food handlers was performed (as part of this study) to identify areas of concern in relation to human factors and food safety in Ireland. The survey returned a number of interesting findings among which was the fact that $63 \%$ of the 100 staff working in the beverage service industry in Ireland did not consider beverages to be 'food'; a misalignment with the definition of food given in EU food law (Regulation (EC) 178/2002). The implication being that food safety risks related to beverages may not be detected or addressed in such a context. In summary, the survey data $(n=100)$ revealed a lack of knowledge of the food safety principals, their regulation, and application, among staff members in the cohort examined. In addition, it implied the need for improvements regarding staff knowledge, food hygiene and human factors related to hygiene practices; particularly with regard to the beverage service industry (Strong, 2017).

An additional study inspecting 12 premises was conducted, using a customised inspection form organised according to the list of violations laid out by Choung (2010): in his analysis of restaurant food safety violations performed in the U.S. in 2009. The inspection checklist contained both human and non-human factors violations. The four subcategories are as follows:

1. Environmental Violations (non human factors related)

2. Cross-Contamination (Human Factors related)

3. Personal Hygiene (Human Factors related)

4. Time and Temperature Abuse (Human Factors related)

These results indicated a general lack of regard for food safety standards in many of the 12 premises inspected in this snap-shot study (Strong, 2017); particularly concerning cross-contamination (Fig. 6).

Training of food handlers is considered one of the most effective strategies for preventing foodborne disease (Rossi et al., 2016), and while training is required under EU food law (Regulation (EC) 852/ 2004), no particular method is specified. This allows FBOs to select a training plan appropriate to their food business e.g. in-house, external, e-learning etc. That said, the FSAI have issued training guidelines for Irish food businesses, including an indicative syllabus, for food handlers (Levels 1 \& 2, Induction and Additional Skills) and managers (Level 3) (FSAI, 2015b). These guidelines greatly assist FBOs (and trainers) in determining the educational needs of their employees, particularly if training of food handlers is carried out in-house.

While a direct relationship between the training of food handlers and knowledge has been reported (Choung, 2010; Rossi et al., 2016), the relationship between knowledge and practice is not always as clear (Park et al., 2010; Da Cunha et al., 2012; Da Cunha et al., 2014; Rossi et al., 2016; Baser et al., 2017). A survey of 50 food handlers in Ireland was conducted in 2016, as part of this study, and $68 \%$ of those surveyed claimed to lose focus/interest during the course of their employment due to the repetitive nature of their work. They also indicated that they believed that good food safety training ( $74 \%$ of those surveyed) and effective food safety management systems (62\% of those surveyed) would help motivate employees to maintain food safety standards. Similarly, Howells et al. (2008) reported that a 'poor attitude regarding food safety' was a barrier to proper food handling, but that appropriate education of the consequences of lapses in hygiene practices would assist FBOs in dealing with this problem.

In addition, 31 certified Irish food safety trainers were also surveyed on food safety training in 2016, as part of this study, and $94 \%$ reported that all food workers should be equipped with a food safety handling manual - as typically distributed at courses by external trainers. One hundred percent of trainers believed that food handlers should be measured against a unified standard, and 93\% suggested that they should be regularly evaluated to determine their competency, suggesting that FBOs should engage in a more stringent and uniform approach to food safety. Sanlier (2009) recommends that training should 
occur at regular intervals during the course of a food handlers employment, while Rowell et al. (2013) suggests that everyday barriers such as time constraints, lack of communication, inadequate resources, and ineffective leadership should also be addressed.

The role of management, in overseeing food safety practices, cannot be underestimated in order to ensure that training undertaken by food handlers is appropriately implemented. Since the effective application of food safety knowledge is an essential part of every food safety management system, certified external training is advised in Ireland by the National Hygiene Partner (NHP) and elsewhere (Campbell et al., 1998; Cotterchio, 1998, Murphy et al., 2011; NHP, 2016); and has been reported as mandatory in 16 out of 50 states in the USA (Schilling et al., 2003). Howells et al., 2008, highlights the importance of appropriate management and the need to incentivise food handlers in order to improve hygiene practices. Moreover, Howells et al. (2008) and Guchait et al. (2016), suggest that managers should be positive 'role models' and reinforce employees behaviour with verbal reminders and praise, to help encourage a healthy food safety culture.

Lastly, Baser et al. (2017) discusses the importance of addressing knowledge gaps and identifying training needs, in particular, taking into account the role/position of each employee being trained. Similarly, Park et al. (2010) recommends the development of more 'jobspecific and hands-on training materials', suggesting a need for more tailored or bespoke food safety programmes: to improve a food handlers knowledge/understanding of the specific areas relevant to his/her dayto-day activities. This recommendation may assist in further enhancing effective food safety practices in role specific activities in a food business.

\subsection{The need to enhance risk assessment in food production}

Research exploring food risk often focus on consumer perceptions of expertly defined risks, stating that consumers overestimate the risk posed by some hazards and underestimate others (Ueland et al., 2012). Modern food systems have been described as highly institutionalised, 'unpredictable, fragmented, and contradictory' (Kjaernes, 2012; Poppe and Kjaernes, 2003). This contributes not only to an increasing divergence in the concerns of producers and consumers regarding what constitutes food risk (Brom, 2000), but also evermore consumer uncertainty and anxiety regarding these risks (Meyer et al., 2012). As such the study of food risk, as it is understood and framed by different agents, is increasingly relevant (Tonkin et al., 2016). Risk management in the food supply chain differs from inspection based controls - as they must be scientifically based and developed from a set of food safety objectives.

A food safety risk assessment strategy should include:

1. Identifying and ranking the risk inherent in the products and activities in production process.

2. Evaluating the risks in terms of the likelihood of their occurrence and the impact, or severity, if they do occur. This process is often called risk mapping and can be undertaken using a decision tree, graphically, or in a matrix.

3. Determining the level of risk the business is willing to accept by the ratio of risk and reward.

Systematic assessment of food safety along the chain is at the core of HACCP, to guarantee the reliability of procedures - this is key, especially in assessing the safety of new food products. General consumer knowledge of and engagement with the production of food, has declined resulting in increasing consumer uncertainty, and sensitivity to, food risks. This is reported to be particularly relevant with regard to new product development (Tonkin et al., 2016). It is important to offer the decision makers tools in the process of new product development, that enable them to: (a) identify the most significant risks from a public health perspective; (b) from a production and operational perspective;

(c) reduce risks, by taking into account the feasibility, effectiveness and cost of possible interventions;

(d) allocate efforts and resources accordingly (CAC, 2011).

BS EN ISO 22000:2005 (BSI London, 2005) defined the approaches to hazard and risk assessment and stated that "in many circumstances, the knowledge and expertise of experienced staff using a structured techniques may be sufficient to manage risk". Checklists are quick and easy to use, and can help determine whether design standards and practices are met and whether previously recognised hazards are properly addressed. In particular, where the experience gained by industry has been incorporated into codes and standards, a high level of safety can be achieved and compliance verified, where for instance structured review techniques were introduced to identify and evaluate previously unforeseen hazards and unintended events (Manning and Soon, 2013). However in the context of new product development, a checklist may not necessarily be an appropriate method; as the process is most likely new and upcoming, and a more tailored process based analysis would be better suited.

\subsection{The need to include the human factors in food risk assessment}

Within this framework there is a need to properly account for human factors in a food production process, as the capacity to foresee human error during everyday work is a nontrivial task (Colombo and Demichela, 2008). Kieffer (1998) argues that: "Frequently the steps in what could for instance be a food production process which involve human factors intervention are the weak links in the process and quite often in validation work the human factors element is ignored while mechanical and technological aspects are studied in great detail".

Risk analysis can bridge that gap, but currently limited research has fully addressed human factors within food safety risk management (Griffith 2006, De Boeck et al., 2015). As pointed out by De Boeck et al. (2015), research has focused on analytical methods, food processing technology, and product formulations (as technological solutions), as well as food safety management systems (as managerial solutions) to improve food safety status in the supply chain. However even a well planned food safety management system cannot guarantee the highest outcome, unless we take into account human behaviour (e.g. the actual execution of procedures), and decision making in an organization; and how they in turn might influence food safety practices (De Boeck et al., 2015).

In particular, few studies truly focus on the possible role that human and organisational errors can have on food safety production; not only in the preliminary hazard analysis phase but in all the stages of the food production and the delivery chain. This is notable, as the majority of food process chains are operated and controlled by humans (Liu and Wang, 2011) and the root causes of the associated risks are human factor related. Moreover, there are limited studies integrating Human Error analysis in food safety management systems in the literature or within the food sector itself (Shirani and Demichela 2015, Milios et al., 2012). One available study was carried out by Shapiro et al. (2011), who investigated the impact of human behaviour on risk perception within the food industry from both an individual and public perspective. In this study, Shapiro et al. were able to identify perceived behavioural control as the strongest predictor of behavioural intentions for both hand washing and food thermometer use. More specifically, attitude was associated with hand washing and subjective norm with thermometer use.

Behaviour is a psychological concept that contains four elements: values, attitudes, perception, and learning (Cox and Cox, 1991). The attitude- forming factors, the incentive factors and learning, all need to be addressed in a coordinated manner to positively influence human behaviours in food production in and to enhance food safety systems. 


\section{The importance of effective food safety management and training in Ireland}

An examination of the Irish CIR for the pathogens Campylobacter spp. Salmonella spp. and Listeria spp., indicate that the rates of infection in Ireland, on average, are lower than our European counterparts. However this is not the case for VTEC, which owing to a high ruminant population and a favourable climate in Ireland, is the highest in Europe (Fig. 4). This is concerning, as the nature of this pathogen (low infectious dose and high virulence) reduces the margin of error available to food handlers in food production, particularly when animal products are an ingredient. The argument for high food safety standards in food preparation is further enforced by the occurrence of a no. of foodborne outbreaks (generally small and low-key) in Ireland - as reported in recent years (Table 1) Maintenance of an effective food safety management system in food businesses in Ireland is not only important from a public health perspective, but also from an economic standpoint. The agri-food sector in Ireland is associated with an estimated 230,000 jobs, has a 26 billion euro turnover (10.5 euro billion of which is exported to 120 countries), and is the most important indigenous industry in Ireland (IBEC, 2017). Moreover, Ireland is the largest net exporter of dairy ingredients, beef, lamb and powdered infant formula in Europe (IBEC, 2017), highlighting the importance of taking every measure to protect this important industry.

'Flexibility' exists in EU food law to allow food businesses to put inplace food safety management systems appropriate to the size and nature of their food business. While this approach is useful, published guides from national authorities and stakeholders are required to assist food businesses in providing practical information on appropriate measures to be taken by food business operators - that are not otherwise indicated in legislation. In Ireland, the FSAI make effective recommendations, publish widely (guidelines, guidance notes, leaflets, etc.) and provide an 'advice line', to support Irish food businesses in complying with food legislation and achieving high standards of food safety. Similarly, while 'flexibility' surrounding training is also useful for food businesses in finding an effective solution in this regard, the authors would suggest that FBOs consider training options carefully. Training (including HACCP training, where relevant) is an essential component of a food safety management system and should be undertaken by all food workers. While in-house training is low-cost and may allow training in specific activities (e.g. cleaning a certain piece of equipment etc.), it is not certified or measured against a standard, and is unlikely to involve a reference manual/material - as recommended by the food safety trainers surveyed for this paper. When considering the option of external training, the FBOs should ensure that the course content covers all necessary areas appropriate to the food handlers role; in Ireland this can be broadly checked against guidelines issued by the FSAI (FSAI, 2015b). In more general terms, external certified training (ensuring a certain level of food safety knowledge has been obtained by the food handler), coupled with some in-house bespoke training on specific elements or role appropriate activities, may provide one such a solution. In addition, formal food safety training for managers and food safety decision makers, combined with frequent refreshers courses, is recommended.

A managers role is 'critical for the success' of a food safety program (Guchait et al., 2016), and they should consistently enact food safety priorities/protocols, convey clear information regarding organisational safety, provide incentives for safety behaviours and model a desired attitude - with the aim of enhancing employees trust and willingness to learn. Their role is to ensure the effective application of food safety training, address knowledge gaps and barriers to implementation, and motivate staff. Regular evaluation of training competency is also recommended to ensure that food safety remains a priority within a food business.

\section{HACCP, HARPC, food safety plans and human factors}

The inclusion of human factors for risk assessment in food preparation processes should also be incorporated in the guidelines connected to BS EN ISO 22000:2005 (BSI London, 2005). HACCP is the key tool for risk assessment and control used in the food supply chain. It can be defined as a systematic preventive approach to consider the potential presence and impact of biological, chemical, and physical (and more recently allergenic) hazards in a production process and in the resulting finished product, and preventing/eliminating or reducing them to an acceptable level. In this context human factors associated with food safety are typically controlled by an effective prerequisite program (PRP), and are not only important for the correct implementation of HACCP, but also underpin all food safety management systems. However, even when prescribed training in GHP and HACCP have been given, it can be difficult for a FBO to motivate disinterested employees who are reticent about engaging in food safety practices when they are not under the 'watchful eye' of a supervisor e.g. lack of hand-washing, prefilling temperature logs, unhygienic practices etc. In addition, optimism bias (an 'it won't happen to me' mentality) is also considered as an additional challenge to the implementation of GHP and the prevention of foodborne illness.

In U.S., the Federal Administration recently reviewed the effectiveness of existing food safety tools, such as Hazard Analysis and Critical Control Point (HACCP), and found them lacking in their capacity to address the need for identification, quantification, control, and management of food safety risks, especially in the grain handling and processing facilities (Sperber, 2005). For this reason, the Food Safety Modernization Act (FSMA) was enacted in the U.S. as a Public Law 111353 on January 4, 2011, amending Title 21 of the United States Code, U.S.C.: Food and Drugs (FDA, 2017). The FSMA legislation is aimed at revamping the existing approach to food safety by focusing, even more closely, on preventive controls (Grover et al., 2016). Section 103 of the new legislation includes the requirements of Hazard Analysis and Risk Based Preventive Controls (HARPC) (Kheradia and Warriner, 2013), In line with this, the traditional approach of using the HACCP (Hazard Analysis Critical Control Point) system will transition to the new HARPC (Hazard Analysis Risk-Based Preventive Controls) system. In addition, the requirements of HARPC are more comprehensive than the traditional HACCP plan (Levin and Newslow 2013), and include more detailed hazard identification and hazard evaluation. In particular it foresees the following seven steps similar to the seven principles present in HACCP - only instead of control points the focus is more acutely on preventive measures:

1. Identify the hazards beyond biological, chemical and physical hazards, including intentional and unintentional contamination

2. Establish Preventive Controls that includes an environmental monitoring program

3. Monitor the effectiveness of your Controls on a routine basis

4. Establish the corrective actions your facility will take, including a food recall plan

5. Verify the steps in your HARPC plan are operating correctly

6. Recordkeeping and Documentation is now mandated by the FDA and must be made available upon verbal or written request

7. Re-evaluate your HARPC plan every 3 years or before any operational change

Fig. 7 provides a high level summary of how human factors elements are intertwined with each of the HRPC steps. In summary there are five elements aligned to these 7 steps:

1. Include intentional and unintentional contamination (human error) in the hazard identification phase

2. Consider human factors in design of equipment and procedure to design them fit for use and mitigate unwanted consequences, taking 


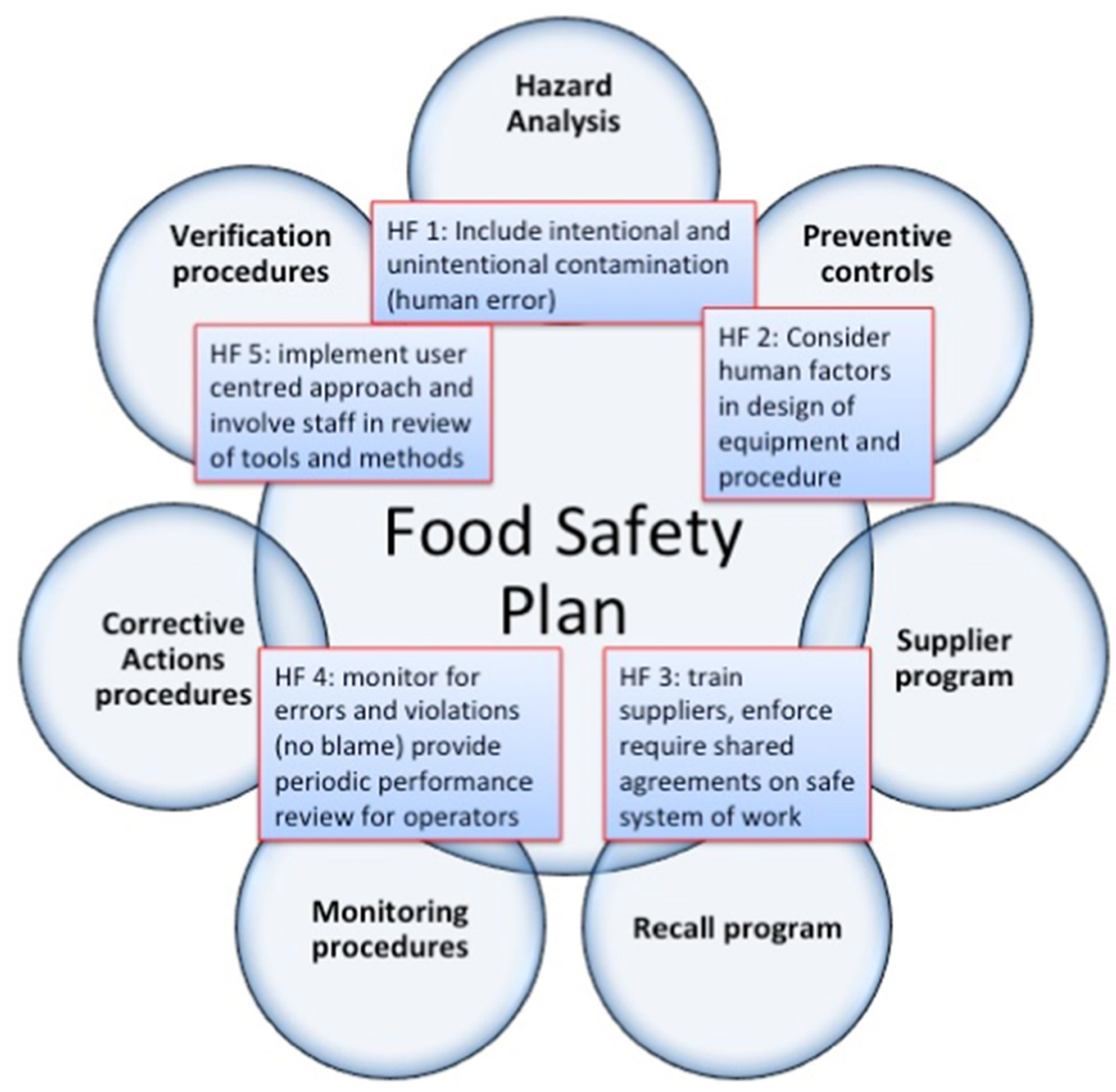

Fig. 7. Human Factors element integrated in the context of a Food Safety Plan.

inspiration form human reliability analysis used at design stage in other sector (Leva et al., 2013, 2015a)

3. Train suppliers, enforce/require shared agreements on safe system of work. Use training as a Safety management mechanism (Cromie et al., 2013)

4. Monitor for errors and violations, building the necessary element of a just reporting culture (Douglas et al., 2014) provide periodic performance review for operators and constructive feedback as it is completed in other industrial sectors (Leva et al., 2015b).

5. Implement a user centred approach and involve staff in the review of tools and methods (as suggested by ISO 31001), and total safety management approaches (Kontogiannis et al., 2017)

From this perspective, FBOs needs to commit time and resources to identifying, risk assessing, and addressing the potential role of 'human error' in their facility - whether intentional, unintentional, direct, or indirect. The 'weakest link' scenario is often used when describing the importance of an adequate traceability system (and its possible breakdown), but similarly this metaphor can be applied to any food safety management system; thereby highlighting the importance of sufficently addressing human factors. For this reason, the FBO should carefully consider the adequacy of measures in-place to prevent or counteract human error, and identifying possible improvements that can be made. These supports may be practical e.g. making sure that soap, sanitizer and paper towels are always available to food handlers, to ensuring that monitoring, documentation, corrective action etc. are being carried out as expected - and if not investigating the reasons why. While additional measures such as internal and external audits can be beneficial in uncovering areas of weakness in a food business (including those associated with food handlers), it will ultimately fall on management to dictate the type of food safety culture that prevails within a food business. Good staff morale, combined with a collegial 'team' ethos will greatly assist FBOs in getting the best out of their employees. Moreover a non-judgemental atmosphere will encourage food handlers to come forward and identify what they perceive as barriers to the implementation of GHP e.g. water in hand washing sink is too hot, dry skin on hands, etc., which can then be addressed.

That said, it is noted that there is an intangible, physiological, aspect to addressing human errors in food production. While rigorous measures should be put in place to ensure food safety is implemented by the FBO, consideration should also be given to more innovative methods of prevention, training, and testing of food handlers. For example, food safety trainers (whether in-house or external) should consider a 'constructivist' approach to training staff e.g. where questions are posed and the students must find the answers - either individually, through group activities, or by using problem-based learning etc. New methods of teaching such as app.'s, e-learning, demonstrations, videos, gamification, etc., could all be harnessed by food safety trainers to improve understanding, interest and engagement. These activities could be incorporated into all aspects of food safety training, as oppose to teaching through text heavy powerpoint slides. For instance if we look at one activity such as hand washing, UV products like 'glo germ' or 'glitterbug' lotion/powder can be used in hand wash training to illuminate potential bacterial contamination on the skin - in order to improve understanding and technique. Similarly, larger facilities may be interested in randomly incorporating testing of the frequency, and quality, of hand washing as part of their food safety management system (as a verification step), such as 'quantitative finger-tip culturing' (Frampton, 2013) - similar to methods used to randomly test hand hygiene of staff in a hospital environment. A pro-active approach to 
teaching and testing food safety can be applied in all areas of training, in order to tackle motivation and compliance issues within a food business.

\section{Conclusions and the way forward}

Breaches and violations in food safety examined in this study, were largely associated with human factors; and mirrored those reported in other studies (globally). This review highlighted the need for a more focused approach to achieving (a) high standards of training among food handlers and managers, and (b) appropriate implementation of food safety principles. Considering the importance of human factors in food safety management, the authors would recommend that FBOs give human factors due attention when compiling their food safety management system. In particular, the potential for human error should be included when carrying out hazard analysis, and in planning preventive and control measures.

In conclusion, in order to make strides in tackling human error, which can lead to breaches in food safety, the $\mathrm{FBO}$ /manager must make the examination, and risk assessment of human factors in their facility a priority. Steps must continue to be taken in Ireland and elsewhere, to examine our risk assessment models, (with human error in mind) and to address staff motivation and training, in order to protect business reputation, and to ensure the safety and quality of the global food supply chain.

\section{Acknowledgements:}

We would like thank the FSAI and HPSC for their assistance in obtaining relevant data for analysis for this review, however any views expressed regarding these data are those of the authors. In addition, we would like to thank Mr. Darren Armstrong and Mr. Dylan Strong and for their contribution of data to this study.

\section{References}

Baser, F., Ture, H., Abubakirova, A., Sanlier, N., Cil, B., 2017. Structural modeling of the relationship among food safety knowledge, attitude and behavior of hotel staff in Turkey Food Control. Food Ctrl. 73, 438-444.

Bolton, D.J., Maunsell, B., 2004. Guidelines for Food Safety Control in European Restaurants. < http://www3.uma.pt/jcmarques/docs/haccp/EUGuidefoodsafety. pdf $>$.

Bolton, D.J., Meally, A., Blair, I.S., McDowell, D.A., Cowan, C., 2008. Food Safety knowledge of head chefs and catering managers in Ireland. Food Cont. 19, 291-300.

Bonner, C., Foley, B., Wall, P., Fitzgerald, M., 2001. Analysis of outbreaks of infectious intestinal disease in Ireland: 1998 and 1999. Irish Med. J. 1 94, 142-144.

Brom, F.W.A., 2000. Food, consumer concerns, and trust: Food ethics for a globalizing market. J. Agri Environ. Ethics 12 (2), 127-139. https://doi.org/10.1023/ a:1009586529518.

CAC, 2011. Guidelines for risk analysis of foodborne antimicrobial resistance, (Codex Alimentarius Commission). CAC/GL 77-2011.

Cagney, C., Crowley, H., Duffy, G., Sherdian, J.J., O’Brien, S., Carney, E., Anderson, W.A., McDowell, D.A., Blair, I.S., 2004. Prevalence and numbers of Escherichia coli O157:H7 in minced beef and beef burgers from butcher shops and supermarkets in the Republic of Ireland. Food Micro. 21, 203-212.

Campbell, Me, Gardner, C.E., Dwyer, J.J., Isaacs, S.M., Krueger, P.D., Ying, J.Y., 1998. Effectiveness of public health interventions in food safety: a systematic review. Cana. J. Pub. Heal. 89, 197-202.

CDC, 2013. Centers for Disease Control and Prevention. Surveillance for foodborne disease outbreaks, United States. < http://www.cdc.gov/foodsafety/pdfs/foodbornedisease-outbreaks-annual-report-2013-508c.pdf >

Chekabab, S.E., Paquin-Veillette, J., Dozois, C.M., Harel, J., 2013. The ecological habitat and transmission of Escherichia coli O157:H7. FEMS Micro. Lett. 341, 1-12.

Choung, J., 2010. An analysis of restaurant food safety violations: human factors, nonhuman factors, and food-borne illness. < http://digitalscholarship.unlv.edu/cgi/ viewcontent.cgi ?article $=1015 \&$ context $=$ thesesdissertations $>$.

Collins, J.E., 1997. Impact of changing lifestyles on the emergence/reemergence of foodborne pathogens. Emer. Infec. Dis 3, 471-479.

Colombo, S., Demichela, M., 2008. The systematic integration of human factors into safety analyses: an integrated engineering approach. Reliab. Eng. Syst. Saf. 93 (12), 1911-1921.

Cotterchio, M., 1998. Effect of a manager training program on sanitary conditions in restaurants. Pub. Health. Rep. 1974, 353-358.

Cox, S., Cox, T., 1991. The structure of employee attitudes to safety: a European example. Work Stress 5 (2), 93-106.
Cromie, S., Liston, P., Ross, D., Corrigan, S., Vani, L., Lynch, D., Demosthenous, V., Leva, M., 2013. Human and organisational factors training as risk management. Chem. Eng. Trans. 33, 445-450. https://doi.org/10.3303/CET1333075. ISSN 2283-9216.

Da Cunha, D.T., Stedefeldt, E., de Rosso, V.V., 2014. The role of theoretical food safety training on Brazilian food handlers knowledge, attitude and practice. Food Cont. 43, 167-174.

Da Cunha, D.T., Stedefeldt, E., de Rosso, V.V., 2012. Perceived risk of foodborne disease by school food handlers and Principals: The influence of frequent training. J. Food Saf. 32, 219-225.

De Boeck, E., Jacxsens, L., Bollaerts, M., Vlerick, P., 2015. Food safety climate in food processing organizations: development and validation of a self-assessment tool. Trends Food Sci. Technol. 46 (2), 242-251.

Douglas, E., Cromie, S., Leva, M., Balfe, N., 2014. Modelling the reporting culture within a modern organisation. Chem. Eng. Trans. 36, 589-594 ISSN: 2283-9216.

EFSA, 2010. The European union summary report on trends and sources of zoonoses, zoonotic agents and food-borne outbreaks in 2008. EFSA J. 8, 1-313.

EFSA, 2015. The European union summary report on trends and sources of zoonoses, zoonotic agents and food-borne outbreaks in 2013. EFSA J. 13, 1-165.

Evans, J.A., Russell, S.I., James, C., Corry, J.E.L., 2004. Microbial contamination of food refrigeration equipment. J. Food Eng. 62, 225-232.

EC, 2009. Guidance document on the implementation of certain provisions of Regulation (EC) No 852/2004 On the hygiene of foodstuffs. < https://www.fsai.ie/ uploadedFiles/EU_Guidance_852.pdf $>$.

Edmonds, S.L., McCormack, R.R., Zhou, S.S., Macinga, D.R., Fricker, C.M., 2012. Hand hygiene regimens for the reduction of risk in food service environments. J. Food Prot. 75, 1303-1309.

FDA, 2009. FDA report on the occurrence of foodborne illness risk factors in selected institutional foodservice, restaurant, and retail food store facility types. < http:// www.fda.gov/downloads/Food/FoodSafety/RetailFoodProtection/ FoodborneIllnessandRiskFactorReduction/RetailFoodRiskFactorStudies/ UCM224682.pdf >

FDA, 2017. Full Text of the Food Safety Moderization Act. https://www.fda.gov/food/ guidanceregulation/fsma/ucm247548.htm.

Fendler, E., Groziak, P., 2002. Efficacy of alcohol-based hand sanitizers against fungi and viruses. Infect. Cont. Hosp. Epid. 23, 61-62.

Frampton, S., 2013. Tackling hand hygiene compliance. < http://www.surewash.com/ wp-content/themes/cocomonio/cocomonio/Clinical\%20Services\%20Jnl\%20IPS $\% 20$ article.pdf $>$.

FSAI, 2013. Risk Management of Norovirus in Oystershttps://www.fsai.ie/publications_ norovirus_opinion/.

FSAI, 2017. FSAI zoonoses reports. < https://www.fsai.ie/enforcement audit/ monitoring/food_surveillance/zoonoses/reports.html > .

FSAI, 2016a. Information received from communications with the FSAI via there advice line.

FSAI, 2016b. 106 Enforcement orders served on food businesses in 2016. < https://www. fsai.ie/news_centre/press_releases/december_2016_enforcements_09012017.html > .

FSAI, 2015a. Annual report 2014. < https://www.fsai.ie/news_annualreport_2014/ > .

FSAI, 2015b. Training guides. < https://www.fsai.ie/food businesses/training guides. html >

FSAI, 2007. Assessmnet of HACCP compliance (revision 2). < https://www.fsai.ie/ WorkArea/DownloadAsset.aspx?id $=738>$.

FSAI, 2004. A surveillance study of E. coli $\mathrm{O} 111$ and E. coli O26 in minced beef on retail sale in Ireland < https://www.fsai.ie/enforcement_audit/monitoring/food_ surveillance/zoonoses/reports/vtec.html $>$.

Fischler, G.E., Fuls, J.L., Dail, E.W., Duran, M.H., Rodgers, N.D., Waggoner, A.L., 2007. Effect of hand wash agents on controlling the transmission of pathogenic bacteria from hands to food. J. Food Prot. 70, 2873-2877.

Gill, C.O., Bryant, J., Badoni, M., 2001. Effect of hot water pasteurising treatment on the microbiological condition of manufacturing beef used for hamburger patty manufacture. Int. J. Food Micro. 63, 243-256.

Griffith, C.J., 2006. Food safety: where from and where to? Br. Food J. 108 (1), 6-15. https://doi.org/10.1108/00070700610637599.

Grover, A.K., Chopra, S., Mosher, G.A., 2016. Food safety modernization act: a quality management approach to identify and prioritize factors affecting adoption of preventive controls among small food facilities. Food Control 66, 241-249.

Guihait, P., Neal, J.A., Simons, T., 2016. Reducing food safety errors in the United States: Leader behavioral integritey for food safety, error reporting, and error management. Int. J. Hosp. Mngt. 59, 11-18.

Guzewich J., Ross M., 1999. Evaluation of risks related to microbial contamination of ready to eat food by food preparation workers and the effectiveness of interventions to minimize those risks. < http://www.journals.wsrpublishing.com/index.php/ tjanrs/article/view/197/430 >

Havelaar, A.H., Kirk, M.D., Torgerson, P.R., Gibb, H.J., Hald, T., Lake, R.J., Praet, N., Bellinger, D.C, de Silva, N.R., Gargouri, N., Speybroeck, N., Cawthorne, A., Mathers, C., Stein, C., Angulo, F.J., Devleesschauwer, B., 2015. World Health Organization global estimates and regional comparisons of the burden of foodborne disease in 2010. < http://journals.plos.org/plosmedicine/article?id=10.1371/journal.pmed. $1001923>$.

Hedberg, C.W., Smith, S.J., Kirkland, E., Radke, V., Jones, T.F., Selman, C.A., the EHS-Net working group, 2006. Systematic environmental evaluations to identify food safety differences between outbreak and non-outbreak restaurants. J. Food Prot. 69, 2697-2702.

Kheradia, A., Warriner, K., 2013. Understanding the food safety modernization act and the role of quality practitioner in the management of food safety and quality systems. TQM J. 25 (4), 347e37.

Kieffer, R.G., 1998. Validation and the human element. PDA J. Pharm. Sci. Technol. 52 
(2), 52-54.

Kjaernes, U., 2012. Ethics and action: a relational perspective on consumer choice in the European politics of food. J. Agric. Environ. Ethics 25 (2), 145e162. https://doi.org/ 10.1007/s10806-011-9315-5.

Kontogiannis, T., Leva, M., Balfe, N., 2017. Total safety management: principles, processes and methods. Saf. Sci. 100, 128-142 ISSN: 0925-7535.

Kruse, H., 2015. Editorial - Food Safety in an International Perspective. WHO. < http:// www.euro.who.int/_data/assets/pdf_file/0004/280093/Food-safety-internationalperspective-EN.pdf?ua $=1>$.

Howells, A.D., Roberts, K.R., Shanklin, C.W., Pilling, V.K., Brannon, L.A., Barrett, B.B., 2008. Restaurant employees' perceptions of barriers to three food safety practices. J. Am. Diet. Assoc. 108, 1345-1349.

HPSC, 2017. Information received via email communications with the HPSC. < http:// www.hpsc.ie $>$.

HPSC, 2011. Report of an international outbreak investigation into a multi-country outbreak of Salmonella Agona, Europe, 2008. < https://www.hpsc.ie/A-Z/ Gastroenteric/Salmonellosis/Outbreaks/File,12549,en.pdf > .

HPSC, 2004. Preventing foodborne disease: a focus on the infected food handler. $<$ https://www.hpsc.ie/A-Z/Gastroenteric/FoodborneIllness/Publications/File,871, en.pdf $>$.

IBEC, 2017. Sector profile. < http://www.fdii.ie/Sectors/FDII/FDII.nsf/vPages/Food Industry_in_Ireland $\sim$ sector-profile? OpenDocument $>$.

Jones, T.F., Angulo, F.J., 2006. Eating in restaurants: a risk factor for foodborne disease? Food Saf. 43, 1324-1327.

Leva, M., Bermudez Angel, C., Plot, E., Gattuso, M., 2013. When the human factor is at the core of the safety barrier. Chem. Eng. Trans. 33, 439-444 ISSN: 2283-9216.

Leva, M.C., Naghdali, F., Ciarapica Alunni, C., 2015a. Human factors in system design: a roadmap for improvement. Proc. CIRP 38, 94-99.

Leva, M., Mattei, F., DelSordo, D., 2015b. Day to day performance management in a small regional airport for safer operations. Cogn. Technol.Work 17, 237-248 ISSN: 14355558.

Levin, B., Newslow, D., 2013. From HACCP to HARPC-what's best in class and how to get there. Webinar Interview-FoodSafetyTech Retrieved February, 21, 2015.

Liu, Wang, Y.-Q., 2011. Operational analysis of the food supply chain. Logist. Technol. 19, 033.

Manning, L., Soon, J., 2013. Mechanisms for assessing food safety risk. Br. Food J. 115 (3), 460-484.

Meyer, S.B., Coveney, J., Henderson, J., Ward, P.R., Taylor, A.W., 2012. Reconnecting Australian consumers and producers: identifying problems of distrust. Food Pol. 37, 634-640. https://doi.org/10.1016/j.foodpol.2012.07.005.

Motarjemi, Y., 2014. Hazard analysis and critical control point system. In: Motarjemi, Y., Lelieveld, H. (Eds.), Food Safety Management: A Practical Guide for the Food Industry. Academic Press, Elsevier, London, UK, pp. 769-798.

Milios, K., Drosinos, E., Zoiopoulos, P., 2012. Factors influencing HACCP implementation in the food industry. J. Hellenic Veterin. Med. Soc. 63 (4), 283-290.

Murphy, K.S., DiPietro, R.B., Kock, G., Lee, J., 2011. Does mandatory food safety training and certification for restaurant employees improve inspection outcomes? Int. J. Hosp. Man. 30, 150-156.

Nayak, R., Waterson, P., 2016. When Food Kills': a socio-technical systems analysis of the UK Pennington 1996 and 2005 E. coli O157 Outbreak reports. Saf. Sc. 86, 36-47.

Nsoesie, E.O., Kluberg, S.A., Brownstein, J.S., 2014. Online reports of foodborne illnes capture foods implicated in official foodborne outbreak reports. Prev. Med. 67, 264-269.

NHP, 2016. The management of food safety (programme text). < http://www.nhp.ie $>$.

Park, S.H., Kwak, T.K., Chang, H.J., 2010. Evaluation of the food safety training for food handlers in restaurant operations. Nut. Res. Pract. 4, 58-68.

Paulson, D.S., Riccardi, C., Beausoleil, C.M., Fendler, E.J., Dolan, M.J., Dunkerton, L.V.,
Williams, R.A., 1999. Efficacy evaluation of four hand cleansing regimes for food handlers. Dairy Food Environ. Sanit. 19, 680-684.

Poppe, C., Kjaernes, U., 2003. Trust in Food in Europe: A Comparative Analysis. National Institute for Consumer Research, Oslo.

Rossi, M.D.S.C., Stedefelt, E., Da Cunha, D.T., De Rosso, V.V., 2016. Food safety knowledge, optimistic bias and risk perception among food handlers in institutional food services. Food Cont. 73, 681-688.

Rotter, M., 1999. Hand washing and hand disinfection. In: Mayhall, C.G. (Ed.), Hospital Epidemiology and Infection Control, second ed. Lippincott Williams \& Wilkins, Philadelphia, USA, pp. 1339-1355.

Rowell, A.E., Binkley, M., Alvarado, C., Thompson, L., Burris, S., 2013. Influence of food safety training on grocery store employees' performance of food handling practices. Food Pol. 41, 177-183.

Ryther, R., 2014. Development of a comprehensive cleaning and sanitizing program for food production facilities. In: Motarjemi, Y., Lelieveld, H. (Eds.), Food Safety Management: A Practical Guide for the Food Industry. Academic Press, Elsevier, London, UK, pp. 741-768.

Safefood, 2008. Listeria and Pregnancy. < http://www.safefood.eu/Publications/ Consumer-info/Pregnancy-and-Listeria.aspx $>$.

Safefood, 2017. Hand Sanitisers - their use and efficacy. < http://www.safefood.eu/ SafeFood/media/SafeFoodLibrary/Documents/Publications/Research\%20Reports/ Report-Hand-Sanitizers-Report-1-June.pdf $>$.

Safefood, 2007. The economic impact of gastroenteritis on the Island of Ireland. < http:// www.safefood.eu/Publications/Research-reports/The-Economic-Impact-ofGastroenteritis-on-the-isla.aspx $>$.

Sanlier, N., 2009. The knowledge and practices of food safety by young and adult consumers. Food Ctrl. 20, 538-542.

Schilling, B.J., O'Connor, J., Hendrickson, V., 2003. State-mandated food safety certification requirements for restaurants: a 2002 review of states. < https://ideas.repec. org/p/ags/rutfwp/18177.html > .

Shapiro, M.A., Porticella, N., Jiang, L.C., Gravani, R.B., 2011. Predicting intentions to adopt safe home food handling practices. applying the theory of planned behavior. Appetite 56, 96-103.

Shirani, M., Demichela, M., 2015. Integration of FMEA and human factor in the food chain risk assessment. Int. J. Soc. Behav. Educ. Econ. Bus. Ind. Eng. 12, 4103-4106.

Sperber, W., 2005. HACCP does not work from farm to table. Food Control 16 (6), $511 \mathrm{e} 514$.

Strong, D., 2017. An empirical review of food safety in the beverage service industry. Thesis submitted as part of BSc. in Environmental Health. Dublin Institute of Technology, Dublin Ireland.

Todd, E.C.D., 2014. Personal hygiene and health. In: Motarjemi, Y., Lelieveld, H. (Eds.), Food Safety Management: A Practical Guide for the Food Industry. Academic Press, Elsevier, London, UK, pp. 769-798.

Tonkin, E., Coveney, J., Meyer, S.B., Wilson, A.B., Webb, T., 2016. Managing uncertainty about food risks e Consumer use of food labeling. Appetite 107, 242-252.

Ueland, Ø., Gunnlaugsdottir, H., Holm, F., Kalogeras, N., Leino, O., Luteijn, J.M., Verhagen, H., 2012. State of the art in benefit-risk analysis: consumer perception. Food Chem. Toxicol. 50 (1), 67e76. https://doi.org/10.1016/j.fct.2011.06.006.

Walsh, C., Duffy, G., O'Mahony, R., Fanning, S., Blair, I.S., McDowell, D.A., 2006. Antimicrobial resistance in Irish isolates of verocytotoxigenic Escherichia coli (E. coli) - VTEC. Int. J. Food. Micro. 109, 173-178.

Walsh, C., Fanning, S., 2008. Antimicrobial resistance in foodborne pathogens. Curr. Drug Targ. 9, 808-815.

WHO, 2017. Media Centre. Food safety fact sheet no.399. < http://www.who.int/ mediacentre/factsheets/fs399/en/ >

WHO, 2003. Several foodborne diseases are increasing in Europe. Press Release EURO/ $16 / 03$. 